\title{
Quantitative Trait Loci (QTLs) mapping for growth traits in the mouse: A review
}

\author{
Pablo M. Corva, Juan F. Medrano* \\ Department of Animal Science, University of California, One Shields Ave., Davis, \\ CA 95616-8521, USA
}

(Received 4 July 2000; accepted 28 November 2000)

\begin{abstract}
The attainment of a specific mature body size is one of the most fundamental differences among species of mammals. Moreover, body size seems to be the central factor underlying differences in traits such as growth rate, energy metabolism and body composition. An important proportion of this variability is of genetic origin. The goal of the genetic analysis of animal growth is to understand its "genetic architecture", that is the number and position of loci affecting the trait, the magnitude of their effects, allele frequencies and types of gene action. In this review, the different strategies developed to identify and characterize genes involved in the regulation of growth in the mouse are described, with emphasis on the methods developed to map loci contributing to the regulation of quantitative traits (QTLs).
\end{abstract}

genetics / growth / mouse / mapping / QTLs

\section{INTRODUCTION}

The mature body size of an animal is determined by the number and size of its cells, and the amount of extracellular matrix and fluid [23], with cell number making a major contribution [2]. A crucial feature of the development of mammals is that at a given point, an animal stops growing, reaching at that point a maximum cell mass. It is accepted that the genetic makeup of the individual plays a predominant role in the determination of that endpoint, but the underlying genetic mechanisms are not well understood [23]. Therefore, one of the primary objectives of the genetic analysis of animal growth is to understand its "genetic architecture", that is the number and position of loci affecting the trait, the magnitude of their effects, allele frequencies and types of gene action $[12,128]$.

The mouse has been extensively used as a model to study the genetics of growth in mammals. Information compiled in the Mouse Genome Database (MGD) [87] gives an idea of the complexity of the genetic regulation of growth

* Correspondence and reprints

E-mail: jfmedrano@ucdavis.edu 
in the mouse. As of March 2001, 650 genes in MGD were described as having some phenotypic effect on growth. In this review, the different strategies developed to identify and characterize genes involved in the regulation of growth in the mouse will be described, with emphasis on the methods developed to map loci associated to the regulation of quantitative traits (QTLs).

\subsection{Selection experiments}

Research on the genetics of animal growth was initially conducted to test the theoretical concepts of quantitative genetics. A hallmark of this work in animal genetics was the development of long-term selection experiments [40] to confirm the efficacy of selection to permanently change the mean of continuous traits in the absence of major mutations, and to verify if there was a limit to the response to selection. The results of these studies showed that most of the growth-related traits had medium-to-high heritability, indicating that additive genetic effects were an important component of the genetic architecture underlying differences in growth. Estimates of realized heritability for body weight and growth rate are in the range between 0.18 and 0.35 [37,83], whereas the estimates corresponding to traits associated with body composition are between 0.18 and 0.66 [38].

Selection experiments also revealed the existence of strong genetic correlations among traits that were indicative of the complexity of growth regulation at both physiological and genetic levels. For example, Hill and Bishop [53] reviewed the results of different selection experiments and concluded that in most cases, selection for growth rate in the mouse increased the level of food intake, improved feed conversion efficiency and enhanced fat deposition, with little change in maintenance requirements and relative growth rate. In contrast, selection for appetite increased both maintenance requirements and growth rate, with little change in conversion efficiency, whereas selection for lean mass increased body weight, keeping body composition and maintenance requirements constant.

Although selection experiments produced a large amount of information pertaining to the genetic regulation of growth, the nature of these experiments, based on mass selection schemes, precluded the identification of individual genes. However, the theoretical model that explained the genetic origin of continuous variation and the response to selection, allowed the estimation of the number of loci regulating a given trait [41]. According to that model, the number of loci involved in the regulation of a quantitative trait is a function of the original additive variance of the base population and the difference of means between the two divergent lines at the selection limit. Given a certain additive variance in the base population, the more loci affecting the trait, the smaller their individual effect and the larger the maximum difference between line means. In a divergent selection experiment for 6-wk weight in mice, the estimated number 
Table I. Summary of single-gene mutations affecting growth in the mouse.

\begin{tabular}{|c|c|c|c|c|}
\hline Mutation & Symbol & Chrom. & Gene responsible & Reference \\
\hline Snell & $d w$ & 16 & $\begin{array}{c}\text { Pituitary specific transcription } \\
\text { factor } 1 \text { (Pit } 1)\end{array}$ & [13] \\
\hline Ames & $d f$ & 11 & $\begin{array}{l}\text { Paired like homeodomain } \\
\text { factor } 1 \text { (Propl) }\end{array}$ & [109] \\
\hline Little & lit & 6 & $\begin{array}{c}\text { GH-releasing } \\
\text { hormone receptor }(G h r h r)\end{array}$ & [50] \\
\hline pygmy & $p g$ & 10 & $\begin{array}{l}\text { High mobility group } \\
\text { protein I, isoform C (Hmgic) }\end{array}$ & [130] \\
\hline miniature & $m n$ & 15 & Unknown & [3] \\
\hline diminutive & $d m$ & 2 & Unknown & [110] \\
\hline high growth & $h g$ & 10 & Socs $2 / \operatorname{Cish} 2$ & {$[6,56]$} \\
\hline
\end{tabular}

of loci affecting growth was 32 [41]. These estimations, however, were based on the assumption that all the involved loci have effects of equal magnitude, and did not take into account the potential increase in additive variance due to new neutral mutations [65]. However, the recent availability of molecular markers and linkage maps has made it possible to perform genome scans to identify QTLs and test the original theoretical hypothesis on the number and magnitude of effects of loci regulating growth. These genome scans involve the systematic screening of markers distributed throughout the genome to identify loci that have significant associations with quantitative traits [114].

\subsection{Single-gene mutations}

An important tool for genetic analysis of growth traits has been the characterization of single-gene mutations producing major phenotypic changes in mice. A summary of known single-gene mutations having a major effect on body size is presented in Table I [81,87]. Three of these mutations, Snell $(d w)$, Ames $(d f)$ and little (lit), affect the Growth Hormone $(\mathrm{GH})$ regulatory pathway at different levels. The pygmy ( $\mathrm{pg}$ ) mutation is due to a disruption of the Hmgic gene on chromosome 10 [130]. The Hmgic gene codes for a High mobility group (HMG) protein. These are very abundant non-histone chromosomal proteins that participate in structural changes to chromatin during transcription [11]. Two other less-known mutations that cause dwarfism in the mouse are miniature $(\mathrm{mn})$ and diminutive $(\mathrm{dm})$. These mutations have been mapped to chromosomes 15 and 2, respectively [87], but the genes responsible for these two mutations are yet to be identified.

In contrast to a fairly high number of known mutations producing a reduction in growth, mouse models of enhanced growth are rare, with the exception of those producing obesity (reviewed by Pomp [100]). The high growth (hg) 
locus, however, is a unique spontaneous, autosomal mutation that enhances weight gain and body size by $30-50 \%$ in the mouse $[6,85]$. Despite the drastic change in growth rate, $h g / h g$ mice are proportionate in the size of tissues and organs [42,111] and are not obese [25]. Genetic and physical mapping have determined that a deletion in chromosome 10 is responsible for this particular phenotype [55]. Recently, the high growth phenotype has been identified as resulting from a lack of expression of the suppressor of cytokine signaling 2 (Socs2 or Cish2) which is partially deleted [56].

\subsection{Transgenics and knockouts}

Targeted gene deletions (gene knockouts) and transgenics are two methods of characterizing the function of a gene which follow opposite strategies. In the case of transgenic mice, extra copies of a gene are integrated at random in the genome of a recipient animal. A dramatic example of the application of this technology to the study of growth genes was presented in the series of experiments involving transgenic mice for the Growth Hormone $(\mathrm{GH})$ gene, described by Palmiter et al. [97,98], and several other groups [19,62,125].

The gene-knockout methodology involves the manipulation of the genome to create loss-of-function phenotypes. In this method, functional alleles are replaced by null alleles in Embryonic Stem (ES) cells that are later integrated into mouse blastocysts [96]. Targeted deletion of two cyclin-dependent kinase (CDK) inhibitors leads to increased body size and organomegalia. Mice homozygous for a deletion on the $p 18^{I N K 4 c}$ gene were $30 \%$ heavier than control mice at 3 months of age [48]. The heart, kidney and liver of those mice were proportionate, whereas the spleen and thymus were disproportionately enlarged. Furthermore, mice lacking p18 developed pituitary adenomas. A very similar phenotype is characteristic of mice lacking the $p 27^{\text {Kip } 1}$ gene [43, 69,93]. Adult mice with two copies of the disrupted gene were $30 \%$ larger than control mice. In addition to their more rapid growth, females had impaired maturation of ovarian follicles.

Targeted disruption experiments have revealed a novel category of growth inhibitors. Cloning of the myostatin gene, a member of the Transforming Growth Factor superfamily $\beta$ (TGF- $\beta$ ) proved the existence of tissue-specific molecules controlling organ size. Mice lacking the myostatin gene have muscles that are up to three times larger than normal [84]. Interestingly, spontaneous mutations on the same gene have been detected in the doublemuscled breeds of beef cattle [61,76]. Myostatin is an extracellular factor expressed almost exclusively in skeletal muscle that affects both cell number and size [84]. The mechanism for the inhibition of growth by myostatin has not been established.

Two elegant targeted disruption experiments were conducted to assess the importance of systemic IGF-I produced by the liver in the regulation of 
growth $[108,126]$. The Igf-I gene was disrupted in hepatic cells using the Cre-loxP recombination system. Targeted expression of the Cre recombinase to the liver was driven by the albumin promoter. The $I g f-I$ gene in non-hepatic tissues was left intact. Surprisingly, suppression of Igf-I expression in the liver had no noticeable effects on growth. At 6 weeks of age, there were no differences in body and femur length, and liver, kidney and heart weights. Only the spleen was smaller in knockout mice. These results emphasize the importance of paracrine and autocrine IGF-I on growth promotion.

A comprehensive list of gene knockouts and transgenics that includes models for the study of growth regulation has been compiled by The Jackson Laboratory in the Transgenic/Targeted Mutation Database ${ }^{1}$. However, knowledge about the phenotype of knockout mice is not enough to categorize a gene as a growth regulator, because impaired growth could be produced as a side effect of a gene that does not normally control growth. Efstratiadis [36] proposed some conditions to be met by a gene in order to consider it involved in growth control: overexpression of a growth-promoting gene should result in overgrowth, whereas gene suppression should produce growth retardation. Opposite results should be obtained with growth-inhibiting genes; however, in this case overgrowth produced by loss of function would constitute sufficient evidence.

\section{GENOME-WIDE SCANS TO IDENTIFY QUANTITATIVE TRAIT LOCI (QTLS)}

The methodologies involving transgenics and targeted gene disruptions require previous knowledge about a gene associated with the phenotype under study. On the contrary, the experimental approach known as positional cloning was developed in order to identify anonymous genes underlying complex traits, without previous knowledge about their functions and based solely on their position in the genome [21,114]. Although the association between markers and quantitative traits has been known for a long time [107], it was the development of molecular techniques that allowed the large scale characterization of polymorphic loci at the DNA level which has permitted the search for loci underlying quantitative variation over the last decade. Initially, Restriction Fragment Length Polymorphisms (RFLP) analyzed by Southern Hybridization were used [5], which in time were replaced by less expensive, PCR based markers such as Simple-Sequence Length Polymorphisms (SSLP) [32]. A new generation of markers, namely the Single Nucleotide Polymorphisms (SNPs), will probably replace the SSLP for linkage analysis, based on promising features such as their abundance in the genome and the possibility of automated typing $[8,9,79]$.

\footnotetext{
1 http://tbase.jax.org/
} 
The available mouse inbred lines are a valuable resource to create mapping populations because the identity and phase of the segregating alleles, of which there are usually only two, are known [45]. However, the methodology has been extended to outbred populations [113] and populations created from selection experiments $[54,64]$.

\subsection{Experimental designs used in QTL mapping}

Usually, one of two alternatives is chosen to create a resource population suitable for QTL mapping. Two inbred mouse lines, usually contrasting for the phenotype of interest, are crossed to produce the $F_{1}$ generation. $F_{1}$ mice are crossed to either one or both of the parental lines to create a backcross, or they are intercrossed to create an $\mathrm{F}_{2}$ population.

Lander and Botstein [74] discussed some of the aspects related to experimental designs in QTL mapping experiments, and concluded that the power to detect QTLs depended on the magnitude of the phenotypic difference between strains, number of segregating QTLs, number of markers and population size. The larger the difference between strains and the fewer the QTLs, the fewer animals needed. According to these authors, if other factors are equal, fewer animals are needed from an $F_{2}$ cross compared to a backcross, because the $F_{2}$ cross provides twice as much meiosis. Another advantage of the $\mathrm{F}_{2}$ over the backcross is that in $F_{2}$ crosses all the segregating alleles can be found in all possible phases among the offspring.

Darvasi [28] derived expressions to calculate the detection power of the most common experimental designs. According to this author, the $F_{2}$ cross would only reduce the number of animals needed to estimate additive effects by $30 \%$ compared to the backcross, because the backcross design requires lower significance thresholds $[73,75]$ and there is also a reduction of the genetic variance compared to the $F_{2}$ cross. Backcrosses are more efficient than $F_{2}$ crosses for the estimation of dominance effects; in equal conditions the same power could be achieved with up to $50 \%$ reduction in population size. Dupuis and Siegmund [35] conducted simulation studies in order to compare different experimental designs. According to their results, an $\mathrm{F}_{2}$ cross is especially more efficient than a backcross when the QTLs have a small additive effect, and when there is dominance with effects of opposite sign to the additive effects. They also concluded that for either design, there was little gain in power when markers were spaced less than $10 \mathrm{cM}$ apart. Apart from all these theoretical considerations, there are also practical issues that influence the choice of a scheme, such as the availability of mice for reproduction and the fertility of $F_{1}$ individuals.

A different approach used to establish linkage to a QTL is to follow changes in allele frequencies between lines produced by long-term divergent selection [49]. Kim and Stephan [67] evaluated the power of the method compared 
to mapping in an $\mathrm{F}_{2}$ cross. For example, a QTL with a given effect that would require an $\mathrm{F}_{2}$ cross of 1050 mice for detection could also be identified after selecting for 14 generations among a population of 90 individuals. However, the power of the method is very sensitive to changes in the number of markers, effective population size and recombination rate between a QTL and a marker. Keightley et al. [64] have successfully applied this method to map QTLs affecting 6-wk body weight.

The strategy known as selective genotyping has been proposed to save time and resources in genome scans. In this method only a fraction of the population corresponding to the animals with extreme phenotypes is genotyped [26,29]. Animals from the extremes of the distribution of phenotypes provide more linkage information [74]. Therefore, up to $80 \%$ of the maximum statistical power can be maintained even if only $50 \%$ of the population from the extremes of the distribution is typed [29]. Although selective genotyping allows to detect linkage disequilibrium between a marker and a QTL, estimation of gene effects is not possible because they would be severely overestimated [29]. Therefore, selective genotyping is usually applied in a two-stage procedure. In the first stage, only extreme animals are typed to find evidence of linkage to QTLs in specific chromosomal regions, and in the second stage the entire population is typed for markers only on the most promising chromosomal regions [90,124].

A variant of the selective genotyping strategy involves the pooling of DNA samples in order to drastically reduce the genotyping work. The existence of linkage between a QTL and a marker is established by assessing if differential allelic representation exists in the pooled DNA samples from extreme individuals, which can be estimated by quantification of the corresponding PCR product. Darvasi and Soller [30] discussed theoretical aspects of selective DNA pooling and derived expressions to calculate the proportion of the population to be genotyped in order to maximize the power of the test. The minimization of technical errors in allele quantification is of particular importance to keep the power of selective genotyping at its maximum. Wang and Paterson [121] discussed other factors affecting the efficiency of the method, such as type of gene action, population type and the existence of segregation distortion. Selective DNA pooling has been successfully used by Taylor and Phillips [116] to map obesity QTLs in the mouse. In this experiment, the contribution from individual animals to the DNA pools was proportional to the difference between their phenotypic value and the population mean, in order to maximize the difference in allelic representation.

\subsection{Statistical analysis}

Manly and Olson [82] have recently reviewed the methods and current software available for QTL mapping. The principles underlying QTL mapping are straightforward. In the simplest case, classification of individuals in the 
population based on their genotype for a given marker makes it possible to compare the phenotypic means of the different genotypic classes [114]. If after the application of a statistical test a significant difference is detected among these classes, it could be deduced that there is a locus affecting the studied trait linked to the marker. There is a limitation to this approach. When single markers are used in the analysis, the magnitude of the QTL effect and its distance to the marker are confounded, e.g. the QTL effects will be underestimated by a factor equal to $(1-2 \times c)$, where $c$ is the recombination rate between the locus and the marker [41]. To overcome this limitation, new mapping strategies have been developed. In the methods based on interval mapping, a pair of markers is analyzed simultaneously and statistical tests determine the most likely position of a QTL within that interval [114]. To perform interval mapping, a fairly dense linkage map is needed in advance [74].

Current methods to map QTLs are based on one of two statistical procedures: maximum likelihood (ML) and regression (least squares) analysis [33]. Leastsquare methods have the advantage of being computationally simpler and easy to implement with any statistical software package [52]; therefore, they have become very popular. They are also robust enough in case of departures from the assumptions of normality. Nonparametric tests have been developed that do not depend on the assumption of normal distribution [72].

Some variants have been introduced into the interval mapping methodology in order to improve the accuracy of QTL detection. The method called composite interval mapping includes markers outside the interval being analyzed in the models, to account for background genetic effects [57,127]. There are programs available that automatically select these cofactors, usually using regression [82].

A statistical problem concerning the levels of significance arises in genomewide scans for QTLs, because a large number of tests are performed which are not statistically independent [73]. Therefore, using an "unprotected" significance level will lead to the detection of many false positives. Lander and Kruglyak [73] proposed a series of standard thresholds to be used in complex trait mapping with the most common experimental designs. Based on genome size, crossing over rate and pointwise significance levels, the recommended thresholds to declare significant linkage (genome-wide $p<0.05$ ) in mouse intercrosses were LOD $=4.3$ and $p=5.2 \times 10^{-5}$. In the case of "suggestive" linkage, the respective values were reduced to $\mathrm{LOD}=2.8$ and $p=1.6 \times 10^{-3}$.

Churchill and Doerge [18] have proposed a method to establish empirical threshold values in genome-wide scans that has become widely accepted by researchers in this area. The method is based on the theory of permutations. Phenotypic values are reassigned at random among individuals while keeping their genotypic information, and the linkage analysis to detect QTLs is performed with the shuffled data set. This process is repeated many times (the 
authors suggested a minimum of 1000 runs), in order to create a distribution of test statistics in the absence of linked QTLs. The 95th percentile value from that distribution would correspond to a significance threshold of $p<0.05$.

Results from QTL mapping experiments should be evaluated with caution. Due to limitations of the experimental design, there is a statistical bias affecting the number and magnitude of effects of reported QTLs [63]. With the current methods for QTL searching, only QTLs with the strongest effects are detected [114]. This bias is inversely related to the stringency of the significance level and it is stronger for dominance effects than for additive effects [63]. Although these limitations of the methodology preclude a faithful characterization of the genetic architecture of a quantitative trait, they still enable us to utilize the information on the position of QTLs. As Kearsey and Farquhar [63] stated, marker-assisted selection and introgression schemes do not require a very accurate estimation of the location of a QTL, and for such purposes researchers would probably be more interested in those QTLs with the strongest effect on the phenotype.

More sophisticated statistical methods are being developed to improve the power of detection in QTL mapping experiments, such as multiple trait analysis [58,71] and multiple interval mapping [128]. Although these methods have not been extensively used to date, they seem to be promising alternatives to the more conventional mapping strategies, and it is likely that they will be adopted by researchers in the field.

\subsection{Experimental QTL studies in mice}

Scientific literature is abundant in results from experiments that have performed genome-wide scans for growth QTLs. These results are summarized in Table II. Results of obesity studies have been reviewed elsewhere [14,100] and will not be included here.

The experiment conducted by Cheverud et al. [16] was one of the first to present results on genome-wide scans for QTLs affecting growth rate and body weight in a fairly large population $\left(535 \mathrm{LG} / \mathrm{J} \times \mathrm{SM} / \mathrm{J}, \mathrm{F}_{2}\right.$ mice $)$. Thirty-one significant loci were identified on 17 chromosomes (QTLs in Tab. II include those that are reported in the MGD database). A very important contribution of this experiment was the identification of independent loci controlling growth at different ages. The experiment was later repeated with $510 \mathrm{~F}_{2}$ mice [120] in order to confirm the results. The second analysis detected QTLs on 15 chromosomes. Not all the QTLs identified in the first experiment were replicated in the second experiment. Replication was low for QTLs with marginal LOD scores and/or on chromosomes with poor marker coverage. Data from both populations were integrated and the analysis was repeated to confirm the existence of QTLs, making this experiment one of the largest that 
has been reported in the literature in terms of population size and number of growth QTLs detected. In the integrated analysis 20 QTLs were found on 17 chromosomes (data shown in Tab. II). Twelve QTLs affected early growth (1-3 wk) whereas 11 QTLs affected late growth (6-10 wk), with 8 common QTLs between both groups. Moreover, four QTLs had sex-specific effects.

An alternative method to the more common mapping approach to segregating crosses was used by Keightley et al. [64] to identify growth QTLs. Two divergent lines were created by recurrent selection for 6-wk body weight starting from a C57BL/6J $(\mathrm{C} 57) \times \mathrm{DBA} / 2 \mathrm{~J} \mathrm{~F}_{2}$ cross. A total of 93 mice from the low line and 34 mice from the high line were genotyped. Significant differences in allele frequency of typed markers between the low and high lines were considered indicative of linkage to growth QTLs. Following this strategy, 11 significant markers were detected on 10 chromosomes.

Morris et al. [91] conducted a QTL scan on a C57 $\times \mathrm{DBA} / 2 \mathrm{~J} \mathrm{~F}_{2}$ cross with 927 mice, in an attempt to replicate the results obtained by Keightley et al. [64]. The studied traits were live weight at 3 and 6 weeks of age, and tail length and body weight at 10 weeks of age. Mice were initially genotyped for the same markers that were significant in the previous experiment [64], and QTLs for 6-wk and 10-wk weight were confirmed on chromosomes 1, 4, 6, 9 and 11. These QTLs accounted for a small proportion of the genetic variance in the population; therefore, more markers were typed in the $\mathrm{F}_{2}$ cross. Selective genotyping was performed on 173 mice (19\% of the population) selected for 10 -wk body weight and carcass fat percentage. The entire $\mathrm{F}_{2}$ cross was genotyped for the most significant markers. QTLs regulating the three measured body weights were identified on chromosome 1. Loci associated with 3-wk weight were identified on chromosomes 4, 9 and 11, respectively. Loci associated with 6-wk weight were mapped to chromosomes 6 and 9, respectively. Significant loci for 10-wk weight were identified on chromosomes 6 and 15 . This experiment was in agreement with previous experiments $[16,120]$ on the existence of specific QTLs regulating growth at different ages. Also, a QTL with very significant effects on tail length was mapped to chromosome 1.

Brockmann et al. [7] mapped growth QTLs in an $\mathrm{F}_{2}$ cross between a line selected for high 6-wk weight (DU6) and a control line (DUK). A total of 715 mice from 4 families were genotyped. Recorded traits were 6-wk weight and liver, spleen and kidney weights. Nine significant QTLs affecting one or more traits were reported.

Two experiments focused on the search for growth QTLs on the X chromosome. Dragani et al. [34] screened two different populations, $(\mathrm{C} 3 \mathrm{H} / \mathrm{He} \times M u s$ spretus $) \times \mathrm{C} 57(\mathrm{HSB})$ and $(\mathrm{A} / \mathrm{J} \times$ Mus spretus $) \times \mathrm{C} 57(\mathrm{ASB})$. Two QTLs affecting 40-wk weight were detected in both populations, and a third QTL was detected only in the ASB cross. 
The differential response in growth rate between males and females from reciprocal crosses between two selected lines, led Rance et al. [103] to hypothesize that an X-linked QTL was involved. The selected lines (P lines) had genetic material from inbred lines JU and CBA and outbred line CFLP. To map the putative QTL an $\mathrm{F}_{2}$ cross between the high and low lines with 340 mice was used. Evidence was produced of a single QTL affecting body weight at 3, 6 and 10 weeks of age. This QTL and the QTL Bwl of Dragani et al. [34] map to the same region of chromosome $\mathrm{X}$.

Two papers reported results obtained with crosses between $\mathrm{C} 57$ and Quackenbush-Swiss (QS) lines. A C57 × C57-QS backcross of 311 mice was typed for markers around the $G h$ and $I g f-I$ genes [20]. Significant association was found between body weight and markers on chromosome 10, but not chromosome 11.

Kirkpatrick et al. [68] evaluated a C57 × IQ5 (QS derived) cross. A total of $200 \mathrm{~F}_{2}$ and $297 \mathrm{C} 57 \times(\mathrm{C} 57 \times$ IQ5) mice were used. Initial analysis of the $\mathrm{F}_{2}$ cross and further analysis of the backcross revealed significant linkage to QTLs regulating 6-wk body weight, 10-wk body weight and adult body weight on chromosomes 4 and 11 .

Other experiments have focused on the search for QTLs related to obesity traits, in which body weight was recorded. A problem arises when body weight is measured close to maturity, because body weight and body fat percentage are correlated. Therefore, the effect of genes influencing linear growth and obesity are confounded. Warden et al. [123] reported a QTL for adult body weight on chromosome 7 in a Spretus $\times$ C57 backcross (designated BSB) of 412 mice. Using 252 mice from the same cross, Lembertas et al. [77] identified a QTL for body length on chromosome $\mathrm{X}$ that had no significant effect on body composition. This QTL probably maps to a similar location to the QTL found by Rance et al. [103].

Pomp et al. [101] mapped QTL for growth and body composition in a M16i $\times(\mathrm{M} 16 \mathrm{i} \times \mathrm{CAST} / \mathrm{Ei})$ backcross. M16i is an inbred line derived from a line selected for high 3-6-wk gain. Twenty mice (5\%) from each extreme of the distribution of 12-wk body weights were genotyped, and markers showing significant departures from expected allele frequencies were typed in the entire population (402 mice). Five significant QTLs were identified on five chromosomes.

Mehrabian et al. [86] conducted a genome-wide scan for obesity QTLs in a $\mathrm{CAST} / \mathrm{Ei} \times \mathrm{C} 57 \mathrm{~F}_{2}$ cross of 200 mice. QTLs for adult $(6 \mathrm{mo}$.) body weight were identified on chromosomes 2 and 15 . The QTL on chromosome 15 also affected body length and was unrelated to obesity traits. The presence of a QTL for adult body weight mapping to the same region of chromosome 2 identified by Mehrabian et al. [86] was detected by Lembertas et al. [78] in 84 mice of a $\mathrm{NZB} / \mathrm{BINJ} \times \mathrm{SM} / \mathrm{J} \mathrm{F}_{2}$ cross. 
Suto et al. [112] looked for modifiers of the effects of the agouti yellow $\left(A^{y}\right)$ allele on adult body weight, in $93 \mathrm{a} / \mathrm{a}$ and $99 A^{y} / a$ mice from a C57 $\times \mathrm{KK}-A^{y}$ $\mathrm{F}_{2}$ cross. KK- $A^{y}$ is an inbred line that develops non-insulin-dependent diabetes and severe obesity. A significant locus for 6 mo. body weight was identified on chromosome 4, in both genotypic classes. Another locus on chromosome 6 was detected as significant in the $A^{y} / a$ group only, which suggests that there was an interaction with the $A^{y}$ allele probably affecting body weight through the degree of fatness.

Moody et al. [90] screened an $\mathrm{F}_{2}$ cross between $\mathrm{C} 57$ and a line (MH) selected for high energy expenditure [94], in order to identify loci associated with the regulation of energy balance and related traits. The C57 line was chosen because it was the line showing the largest differences in energy expenditure when compared to the selected line in a previous experiment [89]. Loci associated with body weight at 3, 6 and 10 wks of age were identified on chromosomes 1 and 17, 1 and 11 and 1, 3 and 11, respectively.

Considering that there are many QTLs involved, directly or indirectly, in determining body size, it is not unexpected to find an overlap in the location of many growth QTLs when different mapping experiments are compared. Therefore, it is valid to speculate about the identity of these QTLs, and pose the question as to whether they correspond to the same genes. Identified QTLs are usually designated by a provisional name that refers to the cross, the trait, and/or the chromosomal location. However, no formal nomenclature rules have yet been proposed for QTLs. Therefore, it is difficult to establish the correspondence between QTLs from different experiments without a detailed analysis of mapping information.

Recently, Keightley and Knott [66] developed a permutation test to evaluate the correspondence among growth QTLs mapped in three different experiments $[7,16,91]$. Surprisingly, no evidence of correspondence between any pair of experiments was found. The authors concluded that a significant correlation between different experiments is unlikely unless there are few QTLs affecting a trait and the populations are related.

The lack of QTL concordance among crosses may also be due to the definition of the phenotypes that have been measured. Growth has been examined as weight at a given age or weight gain in fixed age increments, when perhaps it would be more appropriate to standardize the data, taking into account differences in mature body size. Measurements at the same age are not strictly comparable between lines that differ in mature body size and can be considered as different phenotypes.

\subsection{Epistasis in QTL experiments}

Genes are part of complex networks that regulate all the physiological processes that take place in living organisms [80]. Because genes are integrated 
Table II. Summary of reported QTLs associated with weight gain and body size traits in the mouse. Sources: individual publications, the Human Obesity Gene Map (http://www.obesity.chair.ulaval.ca/Genes.html) and the Mouse Genome Database (http://www.informatics.jax.org/searches/marker_form.shtml).

(continued on the next pages)

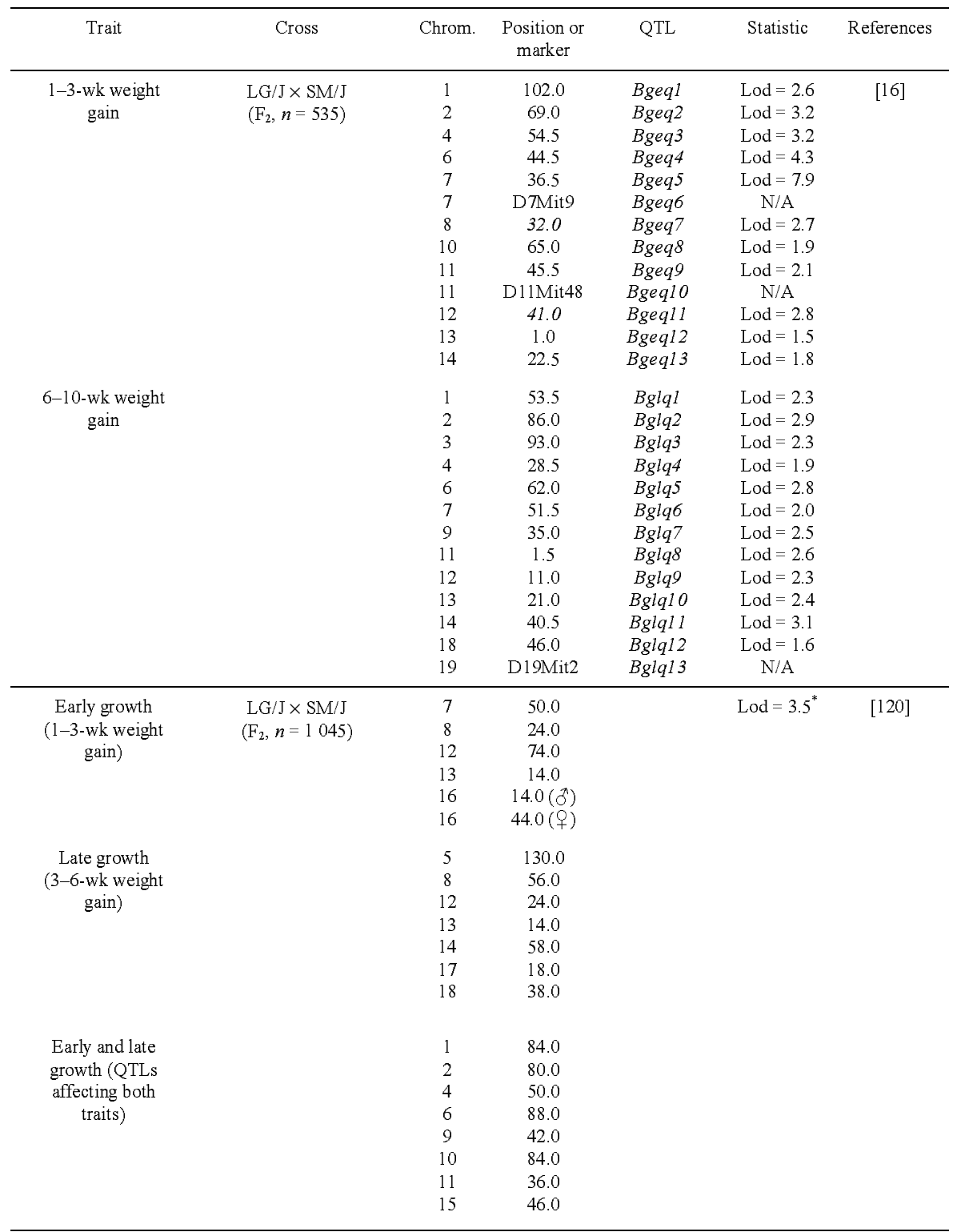


Table II. Continued.

\begin{tabular}{|c|c|c|c|c|c|c|}
\hline Trait & Cross & Chrom. & $\begin{array}{l}\text { Position or } \\
\text { marker }\end{array}$ & QTL & Statistic & References \\
\hline 6-wk body weight & $\begin{array}{c}\text { Divergently selected lines } \\
\text { from a } \\
\text { DBA } 2 \mathrm{~J} \times 57 \mathrm{BL} / 6 \mathrm{~J} \mathrm{~F}_{2} \\
\left(n_{\text {low }}=93 ; n_{\text {high }}=34\right)\end{array}$ & $\begin{array}{c}1 \\
4 \\
5 \\
5 \\
6 \\
7 \\
9 \\
11 \\
13 \\
14 \\
17\end{array}$ & $\begin{array}{c}76.0 \\
26.0 \\
60.0 \\
35.0 \\
22.0 \\
25.0 \\
32.0 \\
45.0 \\
59.0 \\
0.0 \\
14.0\end{array}$ & $\begin{array}{l}B w 6 a \\
B w 6 b \\
B w 6 c \\
B w 6 d \\
B w 6 e \\
B w 6 f \\
B w 6 g \\
B w 6 h \\
B w 6 i \\
B w 6 j \\
B w 6 k\end{array}$ & $\begin{array}{l}\text { Lod }=3.4 \\
\text { Lod }=3.3 \\
\text { Lod }=4.2 \\
\text { Lod }=3.4 \\
\text { Lod }=4.3 \\
\text { Lod }=6.8 \\
\text { Lod }=6.3 \\
\text { Lod }=6.2 \\
\text { Lod }=4.7 \\
\text { Lod }=2.8 \\
\text { Lod }=4.8\end{array}$ & {$[64]$} \\
\hline 3-wk body weight & $\begin{array}{c}\mathrm{DBA} / 2 \mathrm{~J} \times \mathrm{C} 57 \mathrm{BL} / 6 \mathrm{~J} \\
\quad\left(\mathrm{~F}_{2}, n=927\right)\end{array}$ & $\begin{array}{c}1 \\
4 \\
9 \\
11\end{array}$ & $\begin{array}{c}48.3 \\
55.0 \\
8.0 \\
27.8\end{array}$ & & $\begin{array}{l}\text { Lod }=3.7 \\
\text { Lod }=4.4 \\
\text { Lod }=8.3 \\
\text { Lod }=9.5\end{array}$ & [91] \\
\hline 6-wk body weight & & $\begin{array}{l}1 \\
6 \\
9\end{array}$ & $\begin{array}{l}56.4 \\
70.5 \\
50.3\end{array}$ & & $\begin{array}{l}\text { Lod }=3.3 \\
\text { Lod }=3.8 \\
\text { Lod }=3.7\end{array}$ & \\
\hline 10-wk body weight & & $\begin{array}{c}1 \\
6 \\
15\end{array}$ & $\begin{array}{c}54.3 \\
4.0 \\
41.2\end{array}$ & & $\begin{array}{l}\text { Lod }=8.8 \\
\text { Lod }=4.4 \\
\text { Lod }=7.6\end{array}$ & \\
\hline Tail length & & $\begin{array}{l}1 \\
7 \\
9\end{array}$ & $\begin{array}{l}48.3 \\
20.0 \\
12.0\end{array}$ & & $\begin{array}{l}\text { Lod }=32.6 \\
\text { Lod }=4.4 \\
\text { Lod }=4.8\end{array}$ & \\
\hline 6-wk body weight & $\begin{array}{l}\text { DU6 } \times \text { DUK } \\
\left(\mathrm{F}_{2}, n=715\right)\end{array}$ & $\begin{array}{c}11 \\
1 \\
2 \\
4 \\
5 \\
12 \\
13 \\
15 \\
\mathrm{X}\end{array}$ & $\begin{array}{c}42.0 \\
14.0 \\
56.0 \\
55.0 \\
42.0 \\
49.0 \\
34.0 \\
6.0 \\
42.0\end{array}$ & $\begin{array}{l}B w 4 \\
B w 5 \\
B w 6 \\
B w 7 \\
B w 8 \\
B w 9 \\
B w 10 \\
B w 11 \\
B w 12\end{array}$ & $\begin{array}{l}\text { Lod }=4.8 \\
\text { Lod }=4.6 \\
\text { Lod }=5.0 \\
\text { Lod }=4.9 \\
\text { Lod }=4.1 \\
\text { Lod }=3.8 \\
\text { Lod }=4.7 \\
\text { Lod }=4.7 \\
\text { Lod }=3.7\end{array}$ & {$[7]$} \\
\hline 40-wk body weight & $\begin{array}{c}\mathrm{A} / \mathrm{J} \times M . \text { spretus } \\
\times \mathrm{C} 56 \mathrm{BL} / 6 \mathrm{~J}(n \sim 100)\end{array}$ & $\begin{array}{l}\mathrm{X} \\
\mathrm{X} \\
\mathrm{X}\end{array}$ & $\begin{array}{l}\text { DXMit48 } \\
\text { DXMit16 } \\
\text { DXMit35 }\end{array}$ & $\begin{array}{l}B w 1 \\
B w 2 \\
B w 3\end{array}$ & $\begin{array}{l}\text { Lod }=3.4 \\
\text { Lod }=6.6 \\
\text { Lod }=4.3\end{array}$ & {$[34]$} \\
\hline $\begin{array}{l}\text { 3-wk body weight } \\
6 \text {-wk body weight } \\
10 \text {-wk body weight }\end{array}$ & $\begin{array}{l}\text { Selected } \mathrm{P} \text { lines } \\
\quad\left(\mathrm{F}_{2}, n=340\right)\end{array}$ & $\mathrm{X}$ & 23.0 & $Q b w X$ & $\begin{array}{l}\text { Lod }=7.8 \\
\text { Lod }=18.7 \\
\text { Lod }=24.4\end{array}$ & [103] \\
\hline Adult body weight & $\begin{array}{c}\mathrm{QS} \times \mathrm{C} 57 \mathrm{BL} / 6 \mathrm{~J} \\
\text { (backcross to } \mathrm{C} 57, \\
n=311 \text { ) }\end{array}$ & 10 & D10Mit14 & $Q s b w$ & $p<0.009$ & {$[20]$} \\
\hline 6-wk body weight & $\begin{array}{c}\mathrm{IQ} 5 \times \mathrm{C} 57 \mathrm{BL} / 6 \mathrm{~J} \\
\left(\mathrm{~F}_{2}, \mathrm{n}=200 ; \text { backcross to }\right. \\
\mathrm{C} 57, n=297)\end{array}$ & $\begin{array}{c}4 \\
11\end{array}$ & $\begin{array}{c}\text { D4Mit37 } \\
\text { D11Mit231 }\end{array}$ & & $\begin{array}{l}\operatorname{Lod}=2.1 \\
\operatorname{Lod}=3.0\end{array}$ & {$[68]$} \\
\hline Adult body weight & & $\begin{array}{c}4 \\
11\end{array}$ & $\begin{array}{c}\text { D4Mit9 } \\
\text { D11Mit231 }\end{array}$ & & $\begin{array}{l}p<0.032 \\
p<0.038\end{array}$ & \\
\hline
\end{tabular}


Table II. Continued.

\begin{tabular}{|c|c|c|c|c|c|c|}
\hline Trait & Cross & Chrom. & $\begin{array}{l}\text { Position or } \\
\text { marker }\end{array}$ & QTL & Statistic & References \\
\hline Adult body weight & $\begin{array}{c}\mathrm{C} 57 \mathrm{BL} / 6 \mathrm{~J} \times M \text {. spretus } \\
\text { (backcross to C } 57 \\
n=412 \text { ) }\end{array}$ & 7 & D7Mit8 & Mob1 & $\operatorname{Lod}=2.9$ & {$[123]$} \\
\hline Adult body length & $\begin{array}{c}\mathrm{C} 57 \mathrm{BL} / 6 \mathrm{~J} \times M \text {. spretus } \\
\text { (backcross to C } 57 \\
n=252 \text { ) }\end{array}$ & $\mathrm{X}$ & 17.0 & $B d l n$ & Lod $=5.5$ & {$[77]$} \\
\hline 12-wk body weight & $\begin{array}{c}\mathrm{CAST} / \mathrm{Ei} \times \mathrm{M} 16 \mathrm{i} \\
\text { (backcross to CAST, } \\
n=402 \text { ) }\end{array}$ & $\begin{array}{c}2 \\
6 \\
11 \\
15 \\
18\end{array}$ & $\begin{array}{c}\text { D2Mit49 } \\
\text { D6Mit50 } \\
\text { D11Mit5 } \\
\text { D15Mit34 } \\
\text { D18Nds1 }\end{array}$ & & $\begin{array}{c}p<0.001 \\
p<0.01 \\
p<0.001 \\
p<0.001 \\
p<0.001\end{array}$ & {$[101]$} \\
\hline $\begin{array}{l}\text { Adult body length } \\
\text { Adult body weight }\end{array}$ & $\begin{array}{c}\mathrm{C} 57 \mathrm{BL} / 6 \mathrm{~J} \times \mathrm{AST} / \mathrm{Ei} \\
\left(\mathrm{F}_{2}, n=200\right)\end{array}$ & $\begin{array}{l}15 \\
2\end{array}$ & $\begin{array}{l}\text { D15Mit54 } \\
\text { D2Mit50 }\end{array}$ & $B l / B w$ & $\begin{array}{c}\text { Lod }= \\
4.3 / 2.5 \\
\text { N/A }\end{array}$ & {$[86]$} \\
\hline 8-mo. body weight & $\begin{array}{c}\mathrm{ZB} / \mathrm{BINJ} \times \mathrm{SM} / \mathrm{J} \\
\left(\mathrm{F}_{2}, n=84\right)\end{array}$ & 2 & D2Mit28 & Mob5 & $\operatorname{Lod}=4.8$ & {$[78]$} \\
\hline 6-mo. body weight & $\begin{array}{c}\mathrm{C} 57 \mathrm{Bl} / 6 \mathrm{~J} \times \mathrm{KK}-\mathrm{A}^{\mathrm{y}} \\
\left(\mathrm{F}_{2}, \mathrm{a} / \mathrm{a} n=93\right. \\
\left.\mathrm{a} / \mathrm{A}^{\mathrm{y}}=99\right)\end{array}$ & $\begin{array}{l}4 \\
6\end{array}$ & $\begin{array}{c}\text { D4Mit1 } \\
\text { D6Mit361 }\end{array}$ & $\begin{array}{l}B w q 1 \\
B w q 2\end{array}$ & $\begin{array}{l}\text { Lod }=3.1 \\
\text { Lod }=3.4\end{array}$ & {$[112]$} \\
\hline 3-wk body weigh & $\begin{array}{c}\mathrm{C} 57 \mathrm{Bl} / 6 \mathrm{~J} \times \mathrm{MH} \\
\left(\mathrm{F}_{2}, n=560\right)\end{array}$ & $\begin{array}{c}1 \\
1 \\
17\end{array}$ & $\begin{array}{c}72 \\
108 \\
14\end{array}$ & $\begin{array}{l}W t 3 q 1 \\
W t 3 q 2 \\
W t 3 q 3\end{array}$ & $\begin{array}{l}\text { Lod }=5.1 \\
\text { Lod }=10.1 \\
\text { Lod }=6.3\end{array}$ & {$[90]$} \\
\hline 6-wk body weight & & $\begin{array}{c}1 \\
1 \\
11\end{array}$ & $\begin{array}{c}27 \\
108 \\
36\end{array}$ & $\begin{array}{l}W t 6 q 1 \\
W t 6 q 2 \\
W t 6 q 3\end{array}$ & $\begin{array}{l}\text { Lod }=4.0 \\
\text { Lod }=4.0 \\
\text { Lod }=4.6\end{array}$ & \\
\hline 10-wk body weight & & $\begin{array}{c}1 \\
3 \\
11\end{array}$ & $\begin{array}{l}25 \\
61 \\
32\end{array}$ & $\begin{array}{l}W t 10 q 1 \\
W t 10 q 2 \\
W t 10 q 3\end{array}$ & $\begin{array}{l}\text { Lod }=4.3 \\
\text { Lod }=4.8 \\
\text { Lod }=3.6\end{array}$ & \\
\hline $\begin{array}{l}\text { 2-9-wk weight } \\
\text { gain }\end{array}$ & $\begin{array}{c}\mathrm{C} 57 \mathrm{BL} / 6 \mathrm{~J}-h g / h g \\
\times \mathrm{CAST} / \mathrm{Ei} \\
\left(\mathrm{F}_{2}, n=260\right)\end{array}$ & $\begin{array}{c}2 \\
2 \\
11 \\
8\end{array}$ & $\begin{array}{l}31 \\
61 \\
46 \\
45\end{array}$ & $\begin{array}{l}\text { Q2Ucd1-wg29 } \\
\text { Q2Ucd2-wg29 } \\
\text { Q11Ucd1-wg29 } \\
\text { Q8Ucd1-wg29 }\end{array}$ & $\begin{array}{l}\text { Lod }=3.8 \\
\text { Lod }=7.4 \\
\text { Lod }=3.4 \\
\text { Lod }=3.0\end{array}$ & {$[24]$} \\
\hline Carcass protein & & $\begin{array}{c}2 \\
11 \\
17\end{array}$ & $\begin{array}{l}63 \\
46 \\
46\end{array}$ & $\begin{array}{l}Q 2 U c d 2-p r t \\
Q 11 U c d 1-p r t \\
Q 17 U c d 1-p r t\end{array}$ & $\begin{array}{l}\text { Lod }=4.9 \\
\text { Lod }=5.0 \\
\text { Lod }=4.8\end{array}$ & \\
\hline Carcass ash & & $\begin{array}{c}2 \\
11 \\
17\end{array}$ & $\begin{array}{l}63 \\
50 \\
48\end{array}$ & $\begin{array}{l}\text { Q2Ucd2-ash } \\
\text { Q11Ucd1-ash } \\
\text { Q17Ucd1-ash }\end{array}$ & $\begin{array}{l}\text { Lod }=4.3 \\
\text { Lod }=3.2 \\
\text { Lod }=3.7\end{array}$ & \\
\hline Femur length & & $\begin{array}{c}2 \\
9 \\
17\end{array}$ & $\begin{array}{l}59 \\
20 \\
48\end{array}$ & $\begin{array}{l}\text { Q2Ucd2-bo } \\
\text { QUUcd1-bo } \\
\text { Q17Ucd1-bo }\end{array}$ & $\begin{array}{l}\text { Lod }=2.7 \\
\text { Lod }=6.3 \\
\text { Lod }=3.5\end{array}$ & \\
\hline
\end{tabular}

${ }^{*}$ Lod $=3.5$ is a genome-wide significance threshold. Therefore, it can be assumed that all the listed QTLs had individual Lod scores above this value.

$B g e q=$ body growth early QTL; $B g l q=$ body growth late QTL; $B w=$ body weigth; $Q b w=$ QTL body weight; $M o b=$ multigenic obesity; $B d l n=$ body length; $B l / B w=$ body weight and length; $W t=$ body weight; $w 29=$ weight gain from 2 to 9 weeks of age; $p r t=$ carcass protein; $a s h=$ carcass ash; $b o=$ bone trait. 
into regulatory networks, it is sometimes difficult to assign a function to a gene. The apparent lack of a phenotype, already mentioned as a limitation of some gene knockout models, is another example of the complexity of these networks. In a genome-wide scan for QTLs, only those loci that have a significant effect independently of the genetic background will be detected. However, other loci have significant effects on the phenotype only in very specific allelic combinations with other genes. For example, the BSB cross $\left(\mathrm{C} 57 \mathrm{BL} / 6 \mathrm{~J} \times\right.$ Mus spretus $\left.\mathrm{F}_{1} \times \mathrm{C} 57 \mathrm{BL} / 6 \mathrm{~J}\right)$ has a wide range of body fat contents, from extreme leanness to massive obesity, that is not seen either in the parental lines or the $F_{1}$ [122]. There are also examples of QTLs that are detected as significant when pairs of loci are mapped simultaneously, but not when a single-QTL scan is conducted, as has been demonstrated in cases of susceptibility to lung cancer [44] and colon cancer [119] in mice. In the latter experiment, the influence of interactions among loci on cancer susceptibility was inferred because a couple of Recombinant Congenic Strains (RCS) were susceptible, while the parental inbred lines, the $\mathrm{F}_{1}$ and most of the other RCS were resistant. Another possible interaction between QTLs is a drastic change in the magnitude and type of genetic effects of one QTL, depending on the genotype of a second QTL, as demonstrated by Frankel et al. [47] for the frequency of epileptic seizures in mice.

To take into account this level of complexity, epistasis has been included in theoretical models of the genetic regulation of quantitative traits. Epistasis was originally defined as the influence of a gene on the phenotypic expression of a different non-allelic gene; this definition was later extended to any kind of gene interaction [46]. Cheverud and Routman [15] made the distinction between a physiological and a statistical definition of epistasis, that basically correspond to the aforementioned definitions of epistasis in a narrow and broad sense, respectively. The terms "interaction deviation" and "synergism" [46] have also been applied to define non-additive associations among loci.

Although this is currently a very active field of investigation, statistical methods to map QTLs which include the effects of epistasis are still limited. Genetic regulatory networks can include hundreds or even thousands of genes [80]. However, most experiments have only analyzed two-loci interactions between markers [106]. In other cases, interacting QTLs are searched after one significant locus has already been detected [82]. Although not completely satisfactory, these approaches still provide a more comprehensive view of the inter-relationships among loci. One strong limitation of the study of multilocus interactions is population size, because a reduced sample size for each genotypic class prevents a fair estimation of epistatic effects [114]. It is also worth noting that in certain experiments where the existence of epistasis has been addressed, the genetic heterogeneity of the mapping cross has previously been reduced to increase the power of detection. In the case of the above- 
mentioned experiments seeking cancer susceptibility genes [44,119], genetic heterogeneity was reduced by creating RCS, in each of which just a fraction of the genome showed allele segregation [31].

Routman and Cheverud [15] developed a model for the study of two-locus interactions using information from molecular markers. This model was utilized to identify interactions among previously mapped growth QTLs [106]. Forty-three out of 171 pairs of loci showed significant epistatic effects, demonstrating that interactions among loci are a widespread phenomenon in the genetic regulation of growth. Interestingly, the authors suggested that loci exhibiting a larger number of significant interactions could be associated with candidate genes connected to key metabolic pathways regulating growth.

Validation of interactions among loci is a problematic issue in the study of epistasis. One way to achieve this would be by replicating the experiments [73]. Another alternative was used by Rapp et al. [104] who confirmed a two-locus interaction affecting blood pressure in rats by developing single and double congenic strains.

A different approach to exploring the existence of interactions among loci is the search for modifier loci that modulate the phenotypic expression of major single-gene mutations. The existence of such modifiers is usually revealed by the influence that the genetic background exerts on the expression of a mutant phenotype; one example is the degree of severity of a disease of genetic origin [118].

The early experiments of Castle, described by Falconer [40], demonstrated for the first time the influence of genetic modifiers on the phenotype, attributed to a major gene. In 1907, Castle started a divergent selection experiment on Piebald rats to modify the degree of pigmentation. Selection was successful, and backcrosses of the selected lines to unselected stocks proved that changes in the frequency of other genes, as opposed to mutations in the Piebald gene, were responsible for the change in the degree of pigmentation. The existence of genetic modifiers of major mutations was also demonstrated in selection experiments with Drosophila melanogaster. Sturtevant successfully modified the number of bristles in lines carrying the Dichate mutation that normally has an effect of reducing bristle number [40]. Modifier loci have been identified for the most diverse traits in humans [99], animals [4,17] and plants [10], proving that the existence of interactions among loci is a widespread phenomenon, even in the case of major loci.

The experiment reported by Ewart-Toland et al. [39] provides a good example of the utility of the modifier locus approach for the genetic dissection of a complex trait. C57BL/6J-ob/ob mice are obese and have high glucose levels. Both sexes are sterile, and fertility is restored only by leptin treatment. However, $42 \%$ of male mice from a C57BL/6J-ob/ob $\times \mathrm{BALB} / \mathrm{cJ} \mathrm{F}_{2}$ cross were fertile, even without leptin treatment. Four loci capable of restoring the 
fertility of $o b / o b$ males were identified in that cross. Moreover, the actions of these loci did not modify the obesity and diabetic condition of $o b / o b$ mice, proving that these two factors were not responsible for their infertility.

Recently, Corva et al. [24] screened $260 \mathrm{hg} / \mathrm{hg}$ mice from a C57BL/6J$h g / h g \times \mathrm{CAST} / \mathrm{EiJ} \mathrm{F}_{2}$ cross, in order to identify genetic modifiers of $h g$. Nine significant loci associated with different traits were identified. Loci on chromosomes 1, 2 and 8 affected the weight gain of $F_{2}$ mice. Loci on chromosomes 2 and 11 affected weight gain and carcass lean mass (protein and ash). A locus on chromosome 9 modified femur length and another locus on chromosome 17 affected both carcass lean mass and femur length, but neither had significant effects on weight gain. Loci on chromosomes 5 and 9 modified carcass fat content. The typing of selected markers in $+/+$ mice from the same $\mathrm{F}_{2}$ cross revealed significant interactions between $h g$ and four growth QTLs associated with weight gain and body composition on chromosomes 2, 9, 11 and 17. These interactions were detected as changes in gene action (additive or dominant) and in allele substitution effects.

\subsection{Identification of gene/s underlying a QTL}

The ultimate goal of a QTL mapping project is the cloning of the genes responsible for a complex phenotype. In order to achieve that goal, it is usually necessary to complete three consecutive stages: detection of QTLs in a genome scan, estimation of QTL location, and fine mapping [28]. It has been suggested that a degree of resolution of at least 1-cM should be achieved in fine mapping before proceeding to the stage of physical mapping and gene identification [28].

One way to refine the position of a QTL is to do a "genetic chromosome dissection" (GCD) of an interval of interest [27]. The GCD can be performed in mouse crosses using interval-specific congenic strains (ISCS) [27]. This strategy is based on the creation of a series of congenic strains spanning the interval to which a QTL has been mapped. The congenics have a uniform genetic background, and each one carries a different 1-cM segment from a donor line. Phenotypic analysis of the congenics would establish which strains carry the gene to be cloned. The creation of the congenics can be optimized in order to minimize the number of mice needed, as well as the work entailed by phenotyping and genotyping.

The increasing availability of transcript maps for humans and mice have made it possible to develop a variant of the positional cloning method, known as cloning by a positional candidate approach [21]. This method implies searching for genes that could be assigned to a previously mapped QTL due to their location and function. Knowledge about genes in a region of interest simplifies the work of gene identification by chromosome walking, sequencing and contig assembly. The recently redefined objectives of the Human Genome 
Project Consortium contemplate sequencing the entire mouse genome [22]. In fact, the sequencing of BACs harboring loci of special biomedical importance is in progress [95]. This project will soon make the sequences of all mouse genes in public databases available, together with positional information. Therefore, gene identification in the near future will take advantage of comparative genome mapping in the so-called sequence-based era [117]. One example of a strategy that would benefit from this new knowledge to confirm the identity of a QTL would be the creation of transgenic mice through whole BAC or BAC modifications for complementation and rescue of a given phenotype $[1,102]$.

\section{CONCLUDING REMARKS}

The results pertaining to QTL mapping experiments for growth suggest that genetic factors regulating growth can be individualized. Growth QTLs have been mapped to all the mouse chromosomes. Some chromosomes, such as 1 , 4, 6 and 11 seem to be consistently reported as harboring growth QTLs, while others (chromosomes 3, 10, 16, 19) are seldom mentioned. However, this does not take into account differences in chromosome length and choice of lines used in the mapping crosses. There does not seem to be a specific pattern of QTL distribution, and in most cases the map position does not coincide with the location of genes known to affect growth, such as genes controlling hormones and growth factors. The number of QTLs reported in genome-wide scans is extremely variable; therefore it is difficult with the present information to define the number of loci affecting growth. Moreover, there are striking differences in the magnitude of the effects of individual QTLs. Population size seems to be a very important factor limiting the detection power of the different experiments. There are also differences among laboratories in the criteria defining significance thresholds, which contributes to the discrepancy in the number of QTLs affecting a given trait.

With regard to the type of gene action of growth QTLs, no generalizations can be made. There is evidence of additive effects as well as dominance and even overdominance [120] effects on the genetic control of growth traits. For instance, Cheverud et al. [16] reported the existence of underdominance in his experiment.

Even for those experiments in which the highest number of growth QTLs have been detected, only a fraction of the genetic variability has been explained, implying that not all of the genetic factors underlying the trait have been identified. QTL effects are usually expressed as a fraction of the phenotypic variance, making it difficult to estimate the contribution of a QTL to the heritability of a trait. For example, in the experiment of Cheverud et al. [16] mapped QTLs for 10 -wk weight explained $76.1 \%$ of the phenotypic variance, with contributions of single QTL between 1.8\% and 15.2\%, whereas Brockmann et al. [7] reported 
a single QTL on chromosome 11 accounting for up to $35 \%$ of the phenotypic variance of 6-wk body weight. When estimates of the contribution of QTLs to the heritability of a trait have been made, much lower values are obtained. The QTLs identified by Morris et al. [91] accounted for heritabilities of 14\%, $5 \%$ and $12 \%$ for 3, 6 and 10-wk weight, respectively; in the experiment of Keightley et al. [64] the heritability associated with individual markers had values between $0.3 \%$ and $0.7 \%$.

In most cases, the alleles that increase the value of a trait at a particular locus in the mapping cross come from the parental line with a higher phenotypic mean; however, there are exceptions to this rule [16]. In fact, it has been possible to identify growth QTLs in crosses from lines that did not show substantial differences in size [91]. These results emphasize the importance of the genetic background on the effects of a particular QTL.

Independently of the method of choice to search for a QTL, the most challenging task will be the confirmation that a given gene is in reality responsible for the QTL effect. Innovative genetic tools for testing candidate genes are being developed, and they combine the use of transgenics and gene knockouts, the creation of congenic lines [105] and the use of large mutant mouse resources produced by $N$-ethyl- $N$-nitrosourea (ENU) treatment $[59,60]$.

QTL mapping for growth has been a prolific field over the last years. However, a few alternatives can be suggested to accelerate the pace of the process towards the identification of the genes underlying growth QTLs. For example, one of the factors contributing to the lack of correspondence among QTLs, that prevents the confirmation of QTL locations, is the complexity of the phenotypes that are measured when studying the genetics of growth. In fact, complex traits such as growth rate can be considered "life history traits" [66]. The analysis of intermediate phenotypes connected with growth, such as muscle and skeleton size, or even cell number and size in selected tissues, would probably eliminate the so-called "phenotype gap" that exists in the genetic analysis of complex traits [51]. Measurement of specific intermediate phenotypes would also avoid the confounding effects of body composition when studying the genetics of linear growth.

There is also a paucity of experiments investigating interactions among loci (epistasis) in growth regulation. Results reported by Routman and Cheverud [106] on the existence of numerous two-loci interactions affecting body size in the same mapping population used by Cheverud et al. [16], demonstrated that epistasis makes an important contribution to the variability of growth traits in a population.

With regard to the mapping populations used in most experiments, the convenience of using crosses among common inbred lines has undermined the value of wild-derived mouse strains as a source of genetic variability. Therefore, the analysis of some aspects of the genetic architecture of growth 
such as the study of epistasis mentioned above, would require "specialized" populations, such as Recombinant Congenic or Recombinant Inbred strains, in which as many as possible the common lines are represented.

Presently there is no uniform nomenclature in the literature to refer to QTLs, possibly because QTLs are considered to have transitory chromosomal positions until the corresponding gene is identified. However, this lack of nomenclature makes it very difficult to search the literature, to identify QTL location and understand the information underlying the names that they have been given. In order to bring some uniformity to these data and to include searchable information on the QTL names, a consensus nomenclature system needs to be developed by the mouse QTL mapping community.

\section{REFERENCES}

[1] Antoch M.P., Song E.J., Chang A.M., Vitaterna M.H., Zhao Y., Wilsbacher L.D., Sangoram A.M., King D.P., Pinto L.H., Takahashi J.S., Functional identification of the mouse circadian Clock gene by transgenic BAC rescue, Cell 89 (1997) 655-667.

[2] Baserga R., The biology of cell reproduction, Harvard University Press, Cambridge, 1985.

[3] Bennet D., Miniature, a new gene for small size in the mouse, J. Hered. 52 (1961) 95-98.

[4] Bone-Larson C., Basu S., Radel J.D., Liang M., Perozek T., KapoustaBruneau N., Green D.G., Burmeister M., Hankin M.H., Partial rescue of the ocular retardation phenotype by genetic modifiers, J. Neurobiol. 42 (2000) 232-247.

[5] Botstein D., White R.L., Skolnick M., Davis R.W., Construction of a genetic linkage map in man using restriction fragment length polymorphisms, Am. J. Hum. Genet. 32 (1980) 314-331.

[6] Bradford G.E., Famula T.R., Evidence for a major gene for rapid postweaning growth in mice, Genet. Res. 44 (1984) 293-308.

[7] Brockmann G.A., Haley C.S., Renne U., Knott S.A., Schwerin M., Quantitative trait loci affecting body weight and fatness from a mouse line selected for extreme high growth, Genetics 150 (1998) 369-381.

[8] Brookes A.J., The essence of SNPs, Gene 234 (1999) 177-186.

[9] Brookes A.J., Lehväslaiho H., Siegfried M., Boehm J.G., Yuan Y.P., Sarkar C.M., Bork P., Ortigao F., HGBASE: a database of SNPs and other variations in and around human genes, Nucleic Acids Res. 28 (2000) 356-360.

[10] Burnett R.J., Larkins B.A., Opaque2 modifiers alter transcription of the 27-kDa gamma-zein genes in maize, Mol. Gen. Genet. 261 (1999) 908-916.

[11] Bustin M., Lehn D.A., Landsman D., Structural features of the HMG chromosomal proteins and their genes, Biochim. Biophys. Acta 1049 (1990) 231-243.

[12] Byrne P.F., McMullen M.D., Defining genes for agricultural traits: QTL analysis and the Candidate Gene approach, Probe 7 (1996) 24-27. 
[13] Camper S.A., Saunders T.L., Katz R.W., Reeves R.H., The Pit-1 transcription factor gene is a candidate for the murine Snell dwarf mutation, Genomics 8 (1990) 586-590.

[14] Chagnon Y.C., Pérusse L., Weisnagel S.J., Rankinen T., Bouchard C., The human obesity gene map: the 1999 update, Obes. Res. 8 (2000) 89-117.

[15] Cheverud J.M., Routman E.J., Epistasis and its contribution to genetic variance components, Genetics 139 (1995) 1455-1461.

[16] Cheverud J.M., Routman E.J., Duarte F.A.M., van Swinderen B., Cothran K., Perel C., Quantitative Trait Loci for murine growth, Genetics 142 (1996) 13051319.

[17] Chung W.K., Zheng M., Chua M., Kershaw E., Power-Kehoe L., Tsuji M., WuPeng X.S., Williams J., Chua S.C. Jr., Leibel R.L., Genetic modifiers of Leprfa associated with variability in insulin production and susceptibility to NIDDM, Genomics 41 (1997) 332-344.

[18] Churchill G.A., Doerge R.W., Empirical threshold value for quantitative trait mapping, Genetics 138 (1994) 963-971.

[19] Clutter A.C., Pomp D., Murray J.D., Quantitative genetics of transgenic mice: components of phenotypic variation in body weights and weight gains, Genetics 143 (1996) 1753-1760.

[20] Collins A.C., Martin I.C.A., Kirkpatrick B.W., Growth quantitative trait loci (QTL) on mouse Chromosome 10 in a Quackenbush-Swiss $\times$ C57BL/6J backcross, Mamm. Genome 4 (1993) 454-458.

[21] Collins F.S., Positional cloning moves from perditional to traditional, Nat. Genet. 9 (1995) 347-350.

[22] Collins F.S., Patrinos A., Jordan E., Chakravarti A., Gesteland R., Walters L., New goals for the U.S. Human Genome Project: 1998-2003, Science 282 (1998) 682-689.

[23] Conlon I., Raff M., Size control in animal development, Cell 96 (1999) 235-244.

[24] Corva P.M., Horvat S., Medrano J.F., Genetic modifiers of high growth (hg), a mutation that increases body size in the mouse, Mamm. Genome 12 (2001) 284-290.

[25] Corva P.M., Medrano J.F., Diet effects on growth and body composition in high growth (hg/hg) mice, Physiol. Genomics 3 (2000) 17-23.

[26] Darvasi A., The effect of selective genotyping on QTL mapping accuracy, Mamm. Genome 8 (1997) 67-68.

[27] Darvasi A., Interval-specific congenic strains (ISCS): an experimental design for mapping a QTL into a 1-centimorgan interval, Mamm. Genome 8 (1997) 163-167.

[28] Darvasi A., Experimental strategies for the genetic dissection of complex traits in animal models, Nat. Genet. 18 (1998) 19-24.

[29] Darvasi A., Soller M., Selective genotyping for determination of linkage between a marker locus and a quantitative trait locus, Theor. Appl. Genet. 85 (1992) 353-359.

[30] Darvasi A., Soller M., Selective DNA pooling for determination of linkage between a molecular marker and a quantitative trait locus, Genetics 138 (1994) $1365-1373$. 
[31] Démant P., Hart A.A., Recombinant congenic strains: a new tool for analyzing genetic traits determined by more than one gene, Immunogenetics 24 (1986) 416-422.

[32] Dietrich W.F., Miller J., Steen R., Merchant M.A., Damron-Boles D., Husain Z., Dredge R., Daly M.J., Ingalls K.A., O'Connor T.J., et al., A comprehensive genetic map of the mouse genome, Nature 380 (1996) 149-152.

[33] Doerge R.W., Zeng Z.-B., Weir B.S., Statistical issues in the search for genes affecting quantitative traits in experimental populations, Stat. Sci. 12 (1997) 195-219.

[34] Dragani T.A., Zeng Z.B., Canzian F., Gariboldi M., Ghilarducci M.T., Manenti G., Pierotti M.A., Mapping of body weight loci on mouse chromosome X, Mamm. Genome 6 (1995) 778-781.

[35] Dupuis J., Siegmund D., Statistical methods for mapping quantitative trait loci from a dense set of markers, Genetics 151 (1999) 373-386.

[36] Efstratiadis A., Genetics of mouse growth, Int. J. Dev. Biol. 42 (1998) 955-976.

[37] Eisen E.J., The laboratory mouse as a mammalian model for the genetics of growth, in: Proceedings of the 1st World Congress on Genetics Applied to Livestock Production, Madrid, Vol. 1, Editorial Garsi, Madrid, pp. 467-492.

[38] Eisen E.J., Selection experiments for body composition in mice and rats: A review, Livest. Prod. Sci. 23 (1989) 17-32.

[39] Ewart-Toland A., Mounzih K., Qiu J., Chehab F.F., Effect of the genetic background on the reproduction of leptin-deficient obese mice, Endocrinology 140 (1999) 732-738.

[40] Falconer D.S., Early selection experiments, Annu. Rev. Genet. 26 (1992) 1-14.

[41] Falconer D.S., Mackay T.F.C., Introduction to Quantitative Genetics, 4th edn., Longman, Essex, 1996.

[42] Famula T.R., Calvert C.C., Luna E., Bradford G.E., Organ and skeletal growth in mice with a major gene for rapid postweaning growth, Growth Dev. Aging 52 (1988) 145-150.

[43] Fero M.L., Rivkin M., Tasch M., Porter P., Carow C.E., Firpo E., Polyak K., Tsai L.H., Broudy V., Perlmutter R.M., Kaushansky K., Roberts J.M., A syndrome of multiorgan hyperplasia with features of gigantism, tumorigenesis, and female sterility in p27(Kip1)-deficient mice, Cell 85 (1996) 733-744.

[44] Fijneman R.J.A., de Vries S.S., Jansen R.C., Demant P., Complex interactions of new quantitative trait loci, Sluc1, Sluc2, Sluc3 and Sluc4, that influence the susceptibility to lung cancer in the mouse, Nat. Genet. 14 (1996) 465-467.

[45] Fisler J.S., Warden C.H., Mapping of mouse obesity genes: A generic approach to a complex trait, J. Nutr. 127 (1997) 1909S-1916S.

[46] Frankel W.N., Schork N.J., Who's afraid of epistasis?, Nat. Genet. 14 (1996) 371-373.

[47] Frankel W.N., Valenzuela A., Lutz C.M., Johnson E.W., Dietrich W.F., Coffin J.M., New seizure frequency QTL and the complex genetics of epilepsy in EL mice, Mamm. Genome 6 (1995) 830-838.

[48] Franklin D.S., Godfrey V.L., Lee H., Kovalev G.I., Schoonhoven R., ChenKiang S., Su L., Xiong Y., CDK inhibitors p18(INK4c) and p27(Kip1) mediate two separate pathways to collaboratively suppress pituitary tumorigenesis, Genes Dev. 12 (1998) 2899-2911. 
[49] Garnett I., Falconer D.S., Protein variation in strains of mice differing in body size, Genet. Res. 25 (1975) 45-57.

[50] Godfrey P., Rahal J.O., Beamer W.G., Copeland N.G., Jenkins N.A., Mayo K.E., GHRH receptor of little mice contains a missense mutation in the extracellular domain that disrupts receptor function, Nat. Genet. 4 (1993) 227-232.

[51] Graham C.F., Lund G., Zaina S., Growth and the distal tip of mouse chromosome 7, Genet. Res. 72 (1998) 247-253.

[52] Haley C.S., Knott S.A., A simple regression method for mapping quantitative trait loci in line crosses using flanking markers, Heredity 69 (1992) 315-324.

[53] Hill W.G., Bishop S.C., Genetic control of growth, carcass composition and food utilization in laboratory animals, in: Proceedings of the 3rd World Congress on Genetics applied to Livestock Production, Lincoln, Nebraska USA, 16-22 July 1986, Vol. XI, University of Nebraska, Lincoln, pp. 355-366.

[54] Horvat S., Bünger L., Falconer V.M., Mackay P., Law A., Bulfield G., Keightley P.D., Mapping of obesity QTLs in a cross between mouse lines divergently selected on fat content, Mamm. Genome 11 (2000) 2-7.

[55] Horvat S., Medrano J.F., A 500-kb YAC and BAC contig encompassing the high-growth deletion in mouse chromosome 10 and identification of the murine Raidd/Cradd gene in the candidate region, Genomics 54 (1998) 159-164.

[56] Horvat S., Medrano J.F., Lack of Socs 2 expression causes the high growth phenotype in mice, Genomics 72 (2001) 209-212.

[57] Jansen R.C., Stam P., High resolution of quantitative traits into multiple loci via interval mapping, Genetics 136 (1994) 1447-1455.

[58] Jiang C., Zeng Z.-B., Multiple trait analysis of genetic mapping for Quantitative Trait Loci, Genetics 140 (1995) 1111-1127.

[59] Justice M.J., Noveroske J.K., Weber J.S., Zheng B., Bradley A., Mouse ENU mutagenesis, Hum. Mol. Genet. 8 (1999) 1955-1963.

[60] Justice M.J., Zheng B., Woychik R.P., Bradley A., Using targeted large deletions and high-efficiency $\mathrm{N}$-ethyl-N-nitrosourea mutagenesis for functional analyses of the mammalian genome, Methods 13 (1997) 423-436.

[61] Kambadur R., Sharma M., Smith T.P., Bass J.J., Mutations in myostatin (GDF8) in double-muscled Belgian Blue and Piedmontese cattle, Genome Res. 7 (1997) 910-916.

[62] Kaps M., Moura A.S., Safranski T.J., Lamberson W.R., Components of growth in mice hemizygous for a MT/bGH transgene, J. Anim. Sci. 77 (1999) 1148 1154.

[63] Kearsey M.J., Farquhar A.G., QTL analysis in plants; where are we now? Heredity 80 (1998) 137-142.

[64] Keightley P.D., Hardge T., May L., Bulfield G., A genetic map of quantitative trait loci for body weight in the mouse, Genetics 142 (1996) 227-235.

[65] Keightley P.D., Hill W.G., Quantitative genetic variation in body size of mice from new mutations, Genetics 131 (1992) 693-700.

[66] Keightley P.D., Knott S.A., Testing the correspondence between map positions of quantitative trait loci, Genet. Res. 74 (1999) 323-328.

[67] Kim Y., Stephan W., Allele frequency changes in artificial selection experiments: statistical power and precision of QTL mapping, Genet. Res. 73 (1999) $177-184$. 
[68] Kirkpatrick B.W., Mengelt A., Schulman N., Martin I.C., Identification of quantitative trait loci for prolificacy and growth in mice, Mamm. Genome 9 (1998) 97-102.

[69] Kiyokawa H., Kineman R.D., Manova-Todorova K.O., Soares V.C., Hoffman E.S., Ono M., Khanam D., Hayday A.C., Frohman L.A., Koff A., Enhanced growth of mice lacking the cyclin-dependent kinase inhibitor function of p27(Kip1), Cell 85 (1996) 721-732.

[70] Kleyn P.W., Fan W., Kovats S.G., Lee J.J., Pulido J.C., Wu Y., Berkemeier L.R., Misumi D.J., Holmgren L., Charlat O., et al., Identification and characterization of the mouse obesity gene tubby: a member of a novel gene family, Cell 85 (1996) 281-290.

[71] Korol A.B., Ronin Y.I., Kirzhner V.M., Interval mapping of quantitative trait loci employing correlated trait complexes, Genetics 140 (1995) 1137-1147.

[72] Kruglyak L., Lander E.S., A nonparametric approach for mapping quantitative trait loci, Genetics 139 (1995) 1421-1428.

[73] Lander E., Kruglyak L., Genetic dissection of complex traits: guidelines for interpreting and reporting linkage results, Nat. Genet. 11 (1995) 241-247.

[74] Lander E.S., Botstein D., Mapping mendelian factors underlying quantitative traits using RFLP linkage maps, Genetics 121 (1989) 185-199.

[75] Lander E.S., Schork N.J., Genetic dissection of complex traits, Science 265 (1994) 2037-2047.

[76] Lee S.J., McPherron A.C., Myostatin and the control of skeletal muscle mass, Curr. Opin. Genet. Dev. 9 (1999) 604-607.

[77] Lembertas A.V., Fisler J.S., Warden C.H., Wen P.-Z., Xia Y.-R., Lusis A.J., A locus on the $\mathrm{X}$ Chromosome is linked to body length in mice, Mamm. Genome 7 (1996) 171-173.

[78] Lembertas A.V., Pérusse L., Chagnon Y.C., Fisler J.S., Warden C.H., PurcellHuynh D.A., Dionne F.T., Gagnon J., Nadeau A., Lusis A.J., Bouchard C., Identification of an obesity quantitative trait locus on mouse chromosome 2 and evidence of linkage to body fat and insulin on the human homologous region 20q, J. Clin. Invest. 100 (1997) 1240-1247.

[79] Lindblad-Toh K., Winchester E., Daly M.J., Wang D.G., Hirschhorn J.N., Laviolette J.-P., Ardlie K., Reich D.E., Robinson E., Sklar P., Shah N., Thomas D., Fan J.B., Gingeras T., Warrington J., Patil N., Hudson T.J., Lander E.S., Large-scale discovery and genotyping of single-nucleotide polymorphisms in the mouse, Nat. Genet. 24 (2000) 381-386.

[80] Loomis W.F., Sternberg P.W., Genetic networks, Science 269 (1995) 649.

[81] Lyon M.F., Rastan S., Brown S.D.M., Genetic Variants and Strains of the Laboratory Mouse, Vol. 1, 3rd edn., Oxford University Press, Oxford, New York, 1996.

[82] Manly K.F., Olson J.M., Overview of QTL mapping software and introduction to Map Manager QT, Mamm. Genome 10 (1999) 327-334.

[83] McCarthy J.C., The laboratory mouse as a model for animal breeding: a review of selection for increased body weight and litter size, in: Proceedings of the 2nd World Congress on Genetics Applied to Livestock Production, Madrid, Vol. 5, Editorial Garsi, Madrid, pp. 66-83. 
[84] McPherron A.C., Lawler A.M., Lee S.J., Regulation of skeletal muscle mass in mice by a new TGF-beta superfamily member, Nature 387 (1997) 83-90.

[85] Medrano J.F., Pomp D., Sharrow L., Bradford G.E., Downs T.R., Frohman L.A., Growth hormone and insulin-like growth factor-I measurements in high growth $(h g)$ mice, Genet. Res. 58 (1991) 67-74.

[86] Mehrabian M., Wen P.Z., Fisler J., Davis R.C., Lusis A.J., Genetic loci controlling body fat, lipoprotein metabolism, and insulin levels in a multifactorial mouse model, J. Clin. Invest. 101 (1998) 2485-2496.

[87] MGD, "Mouse Genome Database", Vol. 2000: Mouse Genome Informatics, The Jackson Laboratory, Bar Harbor, ME, 2000.

[88] Michaud E.J., Bultman S.J., Stubbs L.J., Woychik R.P., The embryonic lethality of homozygous lethal yellow mice $\left(A^{y} / A^{y}\right)$ is associated with the disruption of a novel RNA-binding protein, Genes Dev. 7 (1993) 1203-1213.

[89] Moody D.E., Pomp D., Nielsen M.K., Variability in metabolic rate, feed intake and fatness among selection and inbred lines of mice, Genet. Res. 70 (1997) $225-235$.

[90] Moody D.E., Pomp D., Nielsen M.K., van Vleck L.D., Identification of quantitative trait loci influencing traits related to energy balance in selection and inbred lines of mice, Genetics 152 (1999) 699-711.

[91] Morris K.H., Ishikawa A., Keightley P.D., Quantitative trait loci for growth traits in C57BL/6J $\times$ DBA/2J mice, Mamm. Genome 10 (1999) 225-228.

[92] Naggert J.K., Fricker L.D., Varlamov O., Nishina P.M., Rouille Y., Steiner D.F., Carroll R.J., Paigen B.J., Leiter E.H., Hyperproinsulinaemia in obese fat/fat mice associated with a carboxypeptidase $\mathrm{E}$ mutation which reduces enzyme activity, Nat. Genet. 10 (1995) 135-142.

[93] Nakayama K., Ishida N., Shirane M., Inomata A., Inoue T., Shishido N., Horii I., Loh D.Y., Mice lacking p27(Kip1) display increased body size, multiple organ hyperplasia, retinal dysplasia, and pituitary tumors, Cell 85 (1996) 707-720.

[94] Nielsen M.K., Jones L.D., Freking B.A., DeShazer J.A., Divergent selection for heat loss in mice: I. Selection applied and direct response through fifteen generations, J. Anim. Sci. 75 (1997) 1461-1468.

[95] National Institute of Health, USA, Trans-NIH Mouse Initiative. http://www.nih.gov/science/models/mouse/index.html

[96] Old R.W., Primrose S.B., Principles of gene manipulation: an introduction to genetic engineering, 5th edn., Blackwell Scientific, Oxford Boston, 1994.

[97] Palmiter R.D., Brinster R.L., Hammer R.E., Trumbauer M.E., Rosenfeld M.G., Birnberg N.C., Evans R.M., Dramatic growth of mice that develop from eggs microinjected with metallothionein-growth hormone fusion genes, Nature 300 (1982) 611-615.

[98] Palmiter R.D., Norstedt G., Gelinas R.E., Hammer R.E., Brinster R.L., Metallothionein-human GH fusion genes stimulate growth of mice, Science 222 (1983) 809-814.

[99] Pedersen O., Genetics of insulin resistance, Exp. Clin. Endocrinol. Diabetes 107 (1999) 113-118.

[100] Pomp D., Genetic dissection of obesity in polygenic animal models, Behav. Genet. 27 (1997) 285-306. 
[101] Pomp D., Cushman M.A., Foster S.C., Drudik D.K., Fortman M., Eisen E.J., Identification of Quantitative Trait Loci for body weight and body fat in mice, in: Proceedings of the 5th World Congress on Genetics applied to Livestock Production, Guelph, Ontario Canada, 7-12 August 1994, Vol. 21, University of Guelph, Guelph, pp. 209-212.

[102] Probst F.J., Fridell R.A., Raphael Y., Saunders T.L., Wang A., Liang Y., Morell R.J., Touchman J.W., Lyons R.H., Noben-Trauth K., Friedman T.B., Camper S.A., Correction of deafness in shaker-2 mice by an unconventional myosin in a BAC transgene, Science 280 (1998) 1444-1447.

[103] Rance K.A., Hill W.G., Keightley P.D., Mapping quantitative trait loci for body weight on the $\mathrm{X}$ chromosome in mice. I. Analysis of a reciprocal $\mathrm{F} 2$ population, Genet. Res. 70 (1997) 117-124.

[104] Rapp J.P., Garrett M.R., Deng A.Y., Construction of a double congenic strain to prove an epistatic interaction on blood pressure between rat chromosomes 2 and 10, J. Clin. Invest. 101 (1998) 1591-1595.

[105] Rikke B.A., Johnson T.E., Towards the cloning of genes underlying murine QTLs, Mamm. Genome 9 (1998) 963-968.

[106] Routman E.J., Cheverud J.M., Gene effects on a quantitative trait: Two-locus epistatic effects measured at microsatellite markers and at estimated QTL, Evolution 51 (1997) 1654-1662.

[107] Sax K., The association of size differences with seed-coat pattern and pigmentation in Phaseolus vulgaris, Genetics 8 (1923) 522-560.

[108] Sjögren K., Liu J.L., Blad K., Skrtic S., Vidal O., Wallenius V., LeRoith D., Törnell J., Isaksson O.G., Jansson J.O., Ohlsson C., Liver-derived insulin-like growth factor I (IGF-I) is the principal source of IGF-I in blood but is not required for postnatal body growth in mice, Proc. Natl. Acad. Sci. USA 96 (1999) 7088-7092.

[109] Sornson M.W., Wu W., Dasen J.S., Flynn S.E., Norman D.J., O’Connell S.M., Gukovsky I., Carrière C., Ryan A.K., Miller A.P., Zuo L., Gleiberman A.S., Andersen B., Beamer W.G., Rosenfeld M.G., Pituitary lineage determination by the Prophet of Pit-1 homeodomain factor defective in Ames dwarfism, Nature 384 (1996) 327-333.

[110] Stevens L.C., Mackensen J.A., The inheritance and expression of a mutation in the mouse affecting blood formation, the axial skeleton, and body size, J. Hered. 49 (1958) 153-160.

[111] Summers P.J., Medrano J.F., Morphometric analysis of skeletal muscle growth in the high growth mouse, Growth Dev. Aging 58 (1994) 135-148.

[112] Suto J., Matsuura S., Imamura K., Yamanaka H., Sekikawa K., Genetics of obesity in $\mathrm{KK}$ mouse and effects of $\mathrm{A}(\mathrm{y})$ allele on quantitative regulation, Mamm. Genome 9 (1998) 506-510.

[113] Talbot C.J., Nicod A., Cherny S.S., Fulker D.W., Collins A.C., Flint J., Highresolution mapping of quantitative trait loci in outbred mice, Nat. Genet. 21 (1999) 305-308.

[114] Tanksley S.D., Mapping polygenes, Annu. Rev. Genet. 27 (1993) 205-233.

[115] Tartaglia L.A., Dembski M., Weng X., Deng N., Culpepper J., Devos R., Richards G.J., Campfield L.A., Clark F.T., Deeds J., et al., Identification and expression cloning of a leptin receptor, OB-R, Cell 83 (1995) 1263-1271. 
[116] Taylor B.A., Phillips S.J., Detection of obesity QTLs on mouse chromosomes 1 and 7 by selective DNA pooling, Genomics 34 (1996) 389-398.

[117] Thomas J.W., Summers T.J., Lee-Lin S.Q., Maduro V., Idol J.R., Mastrian S.D., Ryan J.F., Jamison D.C., Green E.D., Comparative genome mapping in the sequence-based era: early experience with human chromosome 7, Genome Res. 10 (2000) 624-633.

[118] Upadhya P., Churchill G., Birkenmeier E.H., Barker J.E., Frankel W.N., Genetic modifiers of polycystic kidney disease in intersubspecific KAT2J mutants, Genomics 58 (1999) 129-137.

[119] van Wezel T., Stassen A.P.M., Moen C.J.A., Hart A.A.M., van der Valk M.A., Demant P., Gene interaction and single gene effects in colon tumour susceptibility in mice, Nat. Genet. 14 (1996) 468-470.

[120] Vaughn T.T., Pletscher L.S., Peripato A., King-Ellison K., Adams E., Erikson C., Cheverud J.M., Mapping quantitative trait loci for murine growth: a closer look at genetic architecture, Genet. Res. 74 (1999) 313-322.

[121] Wang G.-L., Paterson A.H., Assessment of DNA pooling strategies for mapping of QTLs, Theor. Appl. Genet. 88 (1994) 355-361.

[122] Warden C.H., Fisler J.S., Pace M.J., Svenson K.L., Lusis A.J., Coincidence of genetic loci for plasma cholesterol levels and obesity in a multifactorial mouse model, J. Clin. Invest. 92 (1993) 773-779.

[123] Warden C.H., Fisler J.S., Shoemaker S.M., Weng P.-Z., Svenson K.L., Identification of four chromosomal loci determining obesity in a multifactorial mouse model, J. Clin. Invest. 95 (1995) 1545-1552.

[124] West D.B., Goudey-Lefevre J., York B., Truett G.E., Dietary obesity linked to genetic loci on Chromosomes 9 and 15 in a polygenic mouse model, J. Clin. Invest. 94 (1994) 1410-1416.

[125] Wolf E., Wanke R., Hermanns W., Brem G., Pirchner F., von Butler-Wemken I., Growth characteristics of metallothionein-human growth hormone transgenic mice as compared to mice selected for high eight-week body weight and unselected controls. I. Body weight gain and external body dimensions, Growth Dev. Aging 55 (1991) 225-235.

[126] Yakar S., Liu J. L., Stannard B., Butler A., Accili D., Sauer B., LeRoith D., Normal growth and development in the absence of hepatic insulin-like growth factor I, Proc. Natl. Acad. Sci. USA 96 (1999) 7324-7329.

[127] Zeng Z.-B., Precision mapping of quantitative trait loci, Genetics 136 (1994) $1457-1468$.

[128] Zeng Z.-B., Kao C.H., Basten C.J., Estimating the genetic architecture of quantitative traits, Genet. Res. 74 (1999) 279-289.

[129] Zhang Y., Proenca R., Maffei M., Barone M., Leopold L., Friedman J.M., Positional cloning of the mouse obese gene and its human homologue, Nature 372 (1994) 425-432.

[130] Zhou X., Benson K.F., Ashar H.R., Chada K., Mutation responsible for the mouse pygmy phenotype in the developmentally regulated factor HMGI-C, Nature 376 (1995) 771-774. 